\title{
Critical-metal mineralogy and ore genesis: contributions from the European Mineralogical Conference held in Rimini, September 2016
}

\author{
John F. W. Bowles ${ }^{1, *}$, Nigel J. Cook ${ }^{2}$, Krister Sundblad $^{3,4}$, Erik Jonsson ${ }^{5,6}$, Eimear Deady ${ }^{7,8}$ and \\ HANNAH S. R. Hughes ${ }^{8}$ \\ 1 School of Earth and Environmental Sciences, University of Manchester, Manchester M13 9PL, UK \\ 2 School of Chemical Engineering, The University of Adelaide, Adelaide, SA, 5005, Australia \\ 3 Department of Geography and Geology, FI-20014, University of Turku, Finland \\ 4 Institute of Earth Sciences, 199034, Saint Petersburg State University, Saint Petersburg, Russian Federation \\ 5 Department of Mineral Resources, Geological Survey of Sweden, SE-751 28, Uppsala, Sweden \\ 6 Department of Earth Sciences, Uppsala University, SE-752 36, Uppsala, Sweden \\ 7 British Geological Survey, The Lyell Centre, Research Avenue South, Edinburgh EH14 4AP, UK \\ 8 Camborne School of Mines, University of Exeter, Penryn Campus, Penryn TR10 9EZ, UK
}

CRITICAL raw materials (CRM), often also known collectively as critical metals and minerals, are those that are deemed essential to industry and economic development, but are at risk of supply interruption. The markets and industry of the European Union are dependent on the import of most of the 27 critical raw materials (European Commission, 2017). Although such contrasting materials as baryte, borates, coking coal, natural rubber, fluorspar, graphite, helium and phosphorous/phosphate rock are included in these 27 most critical raw materials, the remaining majority are metals and metalloids, including antimony $(\mathrm{Sb})$, beryllium $(\mathrm{Be})$, bismuth $(\mathrm{Bi})$, cobalt $(\mathrm{Co})$, gallium $(\mathrm{Ga})$, germanium $(\mathrm{Ge})$, hafnium (Hf), indium (In), magnesium ( $\mathrm{Mg}$ ), niobium $(\mathrm{Nb})$, scandium $(\mathrm{Sc})$, tantalum $(\mathrm{Ta})$, tungsten (W), vanadium (V), platinum-group metals (PGM) and the rare-earth elements (REE), the latter which are further subdivided into heavy (HREE) and light (LREE). Of these, the metals deemed to have the highest supply-risk classifications are the REE, $\mathrm{Sb}, \mathrm{Bi}, \mathrm{Mg}$ and $\mathrm{W}$.

In addition to their wide applications throughout high-technology, industry, research and military applications, CRM are now used extensively in the development of green technologies essential to a low-carbon energy future (e.g. high-performance

*E-mail: John.Bowles@manchester.ac.uk

https://doi.org/10.1180/minmag.2017.081.110 neodymium magnets in wind turbines), in innovative technologies such as electric vehicles (cobalt, graphite and lithium as components in batteries), energy-saving lighting technologies (gallium in LEDs), and in technologies that have become everyday items such as smartphones, tablets and $\mathrm{HD}$ televisions (e.g. indium in flat screens and $R E E$ compounds in colour screens). The quantity of CRM in an individual item is often small, but with a large number of items in production, the total demand and consumption is significant. Where CRM are wholly supplied from one region, country or even a single mine, there is a significant potential for problems with supply control, interruption or even cessation due to political or economic pressures. In addition, demands for the sustainable production of raw materials such as cobalt, the REE, tellurium and lithium are predicted to grow beyond current supply rates (Gunn, 2014; Olivetti et al., 2017; Vidal et al., 2017; Rabe et al., 2017; Roskill, 2017).

These concerns have been addressed by the development of numerous industrial and academic collaborations (many of which are reflected in papers in this special issue of Mineralogical Magazine) and these offer a more secure future through innovative exploration methodologies, a deeper understanding of ore genesis or new knowledge about specific deposit types and the potential for extraction of the ore minerals they contain.

The first European Mineralogical Conference (EMC), held in Frankfurt in 2012, was well 
attended and very successful. Participants were struck by the enthusiasm and 'buzz' of the meeting so that we saw the proposal for EMC 2016 in Rimini as an opportunity to discuss topics relevant to the future supply of CRM for Europe. We convened Session 23: 'The future of critical metals: mineralogy, metallogenesis and geometallurgy' and Session 20: 'High-tech metal minerals in Europe' and contributed to Session 22: 'Platinumgroup minerals and accessory minerals: development in their characterisation'. These sessions were well attended and attracted $>70$ oral presentations and posters. There was a deliberate policy to encourage younger workers to contribute. The success of these sessions led to a proposal that this issue of Mineralogical Magazine should be devoted to papers from the meeting and the convenors promptly morphed into guest editors. The next EMC will be held in Kraków in 2020.

This special issue begins with 'Indium and selenium distribution in the Neves-Corvo deposit, Iberian Pyrite Belt, Portugal' (Carvalho et al., 2018) which was the keynote lecture for Session 23. Indium and $\mathrm{Se}$ are most abundant in the $\mathrm{Cu}$-rich ores at Neves-Corvo which is an enigma because In is more abundant in sphalerite than in chalcopyrite. Indium minerals such as roquesite $\left(\mathrm{CuInS}_{2}\right)$ are rare, and Se occurs preferentially in galena. The ore-forming processes and later metamorphism explain the distribution. Overall there is a significant In and Se resource which may be available for future exploitation. The study of In continues with 'Deposition conditions for the indium-bearing polymetallic quartz veins at Sarvlaxviken, southeastern Finland' (Broman et al., 2018). Fluid inclusion studies of the In-rich (up to $1500 \mathrm{ppm}$ ) polymetallic quartz veins show that the metals were derived from an adjacent F-rich granite and associated dykes. Metal deposition occurred at 100 to $500^{\circ} \mathrm{C}$, regardless of vein generation with a chaotic zonation pattern with respect to where in the vein system each metal precipitated.

Emphasizing that CRM are of global interest, the following two papers provide accounts of key ore deposits in South America and Africa. In 'Enrichment in critical metals (In-Ge) and Te-Se in epithermal deposits of the "La Carolina" District, San Luis (Argentina)' (Gallard-Esquivel et al., 2018), epithermal Au-Ag deposits are shown to contain In-rich sphalerite (up to $5490 \mathrm{ppm}$ In) and the $\mathrm{Cu}, \mathrm{Ag}, \mathrm{Ga}, \mathrm{Ge}$ content of the sphalerite suggests a coupled substitution. The paper by Mondillo et al. (2018) looks at 'Critical elements in non-sulfide $\mathrm{Zn}$ deposits: A reanalysis of the Kabwe
$\mathrm{Zn}-\mathrm{Pb}$ ores (central Zambia)' where there are both mixed sulfide and non-sulfide ore bodies. The paper focuses on the non-sulfide mineralization in which a few ppm of $\mathrm{Ga}$ occurs in willemite, sphalerite, goethite and hematite, $\mathrm{Ge}$ is found mainly in willemite and In occurs in goethite and hematite. This partitioning is probably due to the initial $\mathrm{Ga}$, In and $\mathrm{Ge}$ abundances, their different solubilities and their contrasting affinities with the host minerals.

The next sequence of papers addresses deposits containing REE in Scandinavia, Hungary and Australia starting with 'The hydrothermal alteration of carbonatite in the Fen Complex, Norway: mineralogy, geochemistry and implications for rare-earth element resource formation' (Marien et al., 2018). In the Fen carbonatite Complex up to 1.6 wt.\% total REE occurs in hydrothermally altered, so-called rødbergite (hematite-rich carbonatite) due to the breakdown of primary $R E E$ fluorocarbonates and apatite in carbonatite, leading to precipitation of monazite-(Ce) with a ten-fold increase in REE concentration. The highest HREE and Th concentrations occur in the rødbergite whilst the highest $L R E E$ concentrations are in crosscutting rødbergite-rich veins indicating partitioning caused by oxidation of the hydrothermal fluid. Another famous group of REE deposits in Scandinavia is described by: 'Gadolinite-(Nd), a new member of the gadolinite supergroup from $\mathrm{Fe}$ $R E E$ deposits of Bastnäs-type, Sweden' (Škoda et al., 2018). New studies of REE-rich magnetite skarns from the Bergslagen ore province, south central Sweden, have resulted in the discovery of a new Nd-dominant species in the gadolinite group of minerals, gadolinite-(Nd) with an ideal formula of $\mathrm{Nd}_{2} \mathrm{FeBe}_{2} \mathrm{Si}_{2} \mathrm{O}_{10}$. It is monoclinic, $P 21 / c$, with $a=4.8216(3) \AA, b=7.6985(4) \AA, c=10.1362(6) \AA$, with $\beta=90.234(4)^{\circ}, V=376.24(6) \AA^{3}$ and $Z=2$. It is biaxial and weakly pleochroic in shades of green and may originally have been mistaken for törnebohmite-(Ce). The type material is from the Malmkärra mine, but it also occurs in the Johanna and Nya Bastnäs mines and could represent a significant sink for $\mathrm{Nd}$.

Molnár et al. (2018) examine the 'Geochemical characteristics of Triassic and Cretaceous phosphorite horizons from the Transdanubian Mountain Range (western Hungary): genetic implications'. Uranium and REE enrichment in Triassic phosphorite horizons is hosted by carbonate-bearing fluorapatite containing $137-612 \mathrm{ppm} \quad \mathrm{U}$ and 113-261 ppm total $R E E+Y$. In Cretaceous REEenriched nodular phosphorite, carbonate-bearing 
fluorapatite is again the main host for the REE (748-2953 ppm total REE+Y). The Triassic phosphorite was formed by inorganic precipitation in a reducing environment close to sea mounts whilst the Cretaceous occurrence resulted from a concentric growth in cold, ascending seawater at the continental margin under anoxic conditions.

Although not currently exploited, REE are a conspicuous component of the Olympic Dam ironoxide copper gold system, one of the largest ore deposits on Earth. In 'Feldspar mineralogy and rare earth element (re)mobilization in iron-oxide copper gold systems from South Australia: a nanoscale study', Kontonikas-Charos et al. (2018) describe perthitic feldspar textures in granites that host the Olympic Dam deposit and in skarns elsewhere in the same ore province that are anomalously rich in $R E E$, $\mathrm{Ba}$ and $\mathrm{Fe}$ and are sometimes pseudomorphed by assemblages of $R E E$-fluorocarbonates+molybdenite. Concentration of REE occurred during intense metasomatism associated with the transition from a magmatic to hydrothermal fluid regime.

A Sn-Ta deposit in NW Spain is described in 'Textural and mineral-chemistry constraints regarding the columbite-group minerals in the Penouta deposit: evidence of magmatic and fluid-related processes' (Alfonso et al., 2018). This deposit is in a greisenized granitic cupola where Ta minerals occur as disseminations in a leucogranite. Zoned columbite-group minerals (CGM) are the most common Ta-bearing phases, but microlite, wodginite, tapiolite and Ta-rich cassiterite (up to 9 wt.\% $\mathrm{Ta}_{2} \mathrm{O}_{5}$ ) occur also. Dissolution and Ta enrichment of the columbite is probably related to a late-stage granitic fluid.

Papers on platinum-group minerals (PGM) in this special issue include 'The mineralogy, geochemistry and genesis of the alluvial platinum-group minerals of the Freetown Layered Complex, Sierra Leone' (Bowles et al., 2018). Large alluvial PGM-containing $\mathrm{Pt}-\mathrm{Fe}-\mathrm{Cu}$ alloys, laurite-erlichmanite and Os-Ir-Ru alloys differ from the mineral assemblage in the source rocks and the oxidized PGM found in weathered rocks. Features such as dendritic growths and an organic coating support belief in a secondary origin. A second PGM paper examines the mertieite-II structure in 'Mertieite-II, $\mathrm{Pd}_{8} \mathrm{Sb}_{2.5} \mathrm{As}_{0.5}$, crystal-structure refinement and formula revision' (Karimova et al., 2018). The crystal structure of the mertieite-II from Finland is trigonal, space group is $R \overline{3} c$. The unit-cell parameters for two crystals are: $a=7.5172(3) \AA, c=$ 43.037(2) $\AA, V=2106.1(2) \AA^{3}$ and $a=7.5135(4) \AA$, $c=43.003(3) \AA, V=2102.4(3) \AA^{3}$ with $Z=12$. The structure consists of $\mathrm{Sb}$ and $(\mathrm{Sb}, \mathrm{As})$ triangular $3^{6}$, $\mathrm{Pd}$ triangular $3^{6}$ and Pd pentagon-triangular $5.3^{3}$ layers. These are stacked along the $z$ axis to produce an extension of the unit cell that contains 36 layers.

Two papers address molybdenum resources. In the first: 'Fe-, Fe,Mn- and Fe,Mg-chlorite: A genetic linkage to $\mathrm{W},(\mathrm{Cu}, \mathrm{Mo})$ mineralization in the magmatic-hydrothermal system of Borralha, northern Portugal', Bobos et al. (2018) show how chlorite compositions and mineral associations can be linked to the fluids present during mineralization. Fe,Mn-chlorite crystallized from a magmatichydrothermal fluid, whereas $\mathrm{Fe}-$ and $\mathrm{Fe}, \mathrm{Mg}$ chlorite, quartz and adularia owe their origin to a mix of meteoric and magmatic-hydrothermal fluids. Molybdenite from porphyry copper ores occurs at Kalinovskoe and Birgilda (Plotinskaya et al., 2018). In 'Trace-element geochemistry of molybdenite from porphyry $\mathrm{Cu}$ deposits of the Birgilda-Tomino ore cluster (South Urals, Russia)' these authors show that $\mathrm{Si}, \mathrm{Fe}, \mathrm{Co}, \mathrm{Cu}, \mathrm{Zn}, \mathrm{Ag}, \mathrm{Sb}$, $\mathrm{Te}, \mathrm{Pb}, \mathrm{Bi}, \mathrm{Au}, \mathrm{As}$ and $\mathrm{Se}$ form mineral inclusions within molybdenite with very variable Re contents. A temperature decrease favours the formation of Re-rich molybdenite which, with compositional heterogeneity, suggests a mantle source for the molybdenum.

Although gold is not among the critical raw materials of today, largely due to the diverse sources of supply, the global economic impact of changing gold prices is significant so a fundamental understanding of genesis of gold deposits is vital. 'Supergene gold enrichment in the CastromilSerra da Quinta gold deposit, NW Portugal' (Cruz et al., 2018) shows that gold deposits hosted by Variscan granites and Precambrian to Palaeozoic metasediments are marked by gossans that were exploited by early miners. Early-formed gold in primary sulfides (arsenopyrite and pyrite) contains 15-40 wt.\% Ag whilst later gold occurring along grain boundaries and in microfractures in the sulfides or in associated quartz veins contains more Ag (37-52 wt.\%). Supergene gold in the gossan contains $<16 \mathrm{wt} . \% \mathrm{Ag}$ as a result of gold enrichment during weathering.

\section{Acknowledgements}

Giuseppe Cruciani and Bernardo Cesare with their team from Società Italiana di Mineralogia e Petrologia and the International EMC committee organized an excellent meeting in Rimini. The sessions on critical metals, high-tech metals and the platinum-group 
metals were boosted by the enthusiasm of the contributors and participants. Generous funding by the Applied Mineralogy Group of the Mineralogical Society of Great Britain \& Ireland, the Commission on Ore Mineralogy of the International Mineralogical Association, the Dipartimento di Scienze della Terra, dell'Ambiente e delle Risorse, Università degli Studi di Napoli Federico II, Napoli Italy, the Geological Survey of Sweden (SGU) and by the K.H. Renlund Foundation, Finland has enabled this issue of Mineralogical Magazine to be published as Open Access.

\section{References}

Alfonso, P., Hamid, S.A., Garcia-Valles, M., Llorens, T., López Moro, F.J., Tomasa, O., Calvo, D., Guasch, E., Anticoi, H., Oliva, J., Parcerisa, D. and García Polonio, F. (2018) Textural and mineral-chemistry constraints regarding the columbite-group minerals in the Penouta deposit: evidence from magmatic and fluid-related processes. Mineralogical Magazine, 82, S199-S222.

Bobos, I., Noronha, F. and Mateus, A. (2018) Fe-, Fe,Mnand $\mathrm{Fe}, \mathrm{Mg}$-chlorite: A genetic linkage to $\mathrm{W},(\mathrm{Cu}, \mathrm{Mo})$ mineralization in the magmatic-hydrothermal system of Borralha, northern Portugal. Mineralogical Magazine, 82, S259-S279.

Bowles, J F.W., Suárez, S., Prichard, H.M. and Fisher, P.C. (2018) The mineralogy, geochemistry and genesis of the alluvial platinum-group minerals of the Freetown Layered Complex, Sierra Leone. Mineralogical Magazine, 82, S223-S246.

Broman, C., Sundblad, K., Valkama, M. and Villar, A. (2018) Deposition conditions for the indium-bearing polymetallic quartz veins at Sarvlaxviken, southeastern Finland. Mineralogical Magazine, 82, S43-S59.

Carvalho, J.R.S., Relvas, J.M.R.S., Pinto, A.M.M., Frenzel, M., Krause, J., Gutzmer, J., Pacheco, N., Fonseca, R., Santos, S., Caetano, P., Reis, T. and Gonçalves, M. (2018) Indium and selenium distribution in the Neves-Corvo deposit, Iberian Pyrite Belt, Portugal. Mineralogical Magazine, 82, S5-S41.

Cruz, C., Noronha, F., Santos, P., Mortensen, J.K. and Lima, A. (2018) Supergene gold enrichment in the Castromil-Serra da Quinta gold deposit, NW Portugal. Mineralogical Magazine, 82, S307-S320.

European Commission (2017) Communication from the Commission to the European Parliament, the Council, the European Economic and Social Committee and the Committee of the Regions on the 2017 list of Critical Raw Materials for the EU: http://eur-lex.europa.eu/ legal-content/EN/ALL/?uri=COM:2017:0490:FIN.

Gallard-Esquivel, M.C., Cepedal, A., Fuertes-Fuente, M. and Martin-Izard, A. (2018) Enrichment in critical metals (In-Ge) and Te-Se in epithermal deposits of the
'La Carolina' District, San Luis (Argentina). Mineralogical Magazine, 82, S61-S87.

Gunn, G. (editor) (2014) Critical Metals Handbook, first edition. American Geophysical Union and John Wiley \& Sons, Oxford, UK, 454 pp.

Karimova, O.V., Zolotarev, A.A., Evstigneeva, T.L. and Johanson, B. (2018) Mertieite-II, $\mathrm{Pd}_{8} \mathrm{Sb}_{2.5} \mathrm{As}_{0.5}$, crystal-structure refinement and formula revision. Mineralogical Magazine, 82, S247-S257.

Kontonikas-Charos, A., Ciobanu, C.L., Cook, N.J., Ehrig, K., Ismail, R., Krneta, S. and Basak, A. (2018) Feldspar mineralogy and rare-earth element (re) mobilization in iron-oxide copper gold systems from South Australia: a nanoscale study. Mineralogical Magazine, 82, S173-S197.

Marien, C., Dijkstra, A.H. and Wilkins, C. (2018) The hydrothermal alteration of carbonatite in the Fen Complex, Norway: mineralogy, geochemistry and implications for rare-earth element resource formation. Mineralogical Magazine, 82, S115-S131.

Molnár, Z., Kiss, G.B., Dunk1, I., Czuppon, G., Zaccarini, F. and Dódony, I. (2018) Geochemical characteristics of Triassic and Cretaceous phosphorite horizons from the Transdanubian Mountain Range (western Hungary): genetic implications. Mineralogical Magazine, 82, S147-S171.

Mondillo, N., Herrington, R., Boyce, A.J., Wilkinson, C., Santoro, L. and Rumsey, M. (2018) Critical elements in nonsulfide $\mathrm{Zn}$ deposits: A reanalysis of the Kabwe $\mathrm{Zn}-\mathrm{Pb}$ ores (central Zambia). Mineralogical Magazine, 82, S89-S114.

Olivetti, E.A., Ceder, G., Gaustad, G.G. and Fu, X. (2017) Lithium-ion battery supply chain considerations: analysis of potential bottlenecks in critical metals. Joule, 1, 229-243.

Plotinskaya, O.Y., Abramova, V.D., Groznova, E.O., Tessalina, S.G., Seltmann, R. and Spratt, J. (2018) Trace element geochemistry of molybdenite from porphyry $\mathrm{Cu}$ deposits of the Birgilda-Tomino ore cluster (South Urals, Russia). Mineralogical Magazine, 82, S281-S306.

Rabe, W., Kostka, G. and Stegen, K.S. (2017) China's supply of critical raw materials: Risks for Europe's solar and wind industries? Energy Policy, 101, 692-699.

Roskill (2017) Rare Earths. Global Industry, Markets and Outlook 2017. Roskill Information Services, London, $396 \mathrm{pp}$.

Škoda, R., Plášil, J., Čopjaková, R., Novák, M, Jonsson, E., Galiová, M.V. and Holtstam, D. (2018) Gadolinite$(\mathrm{Nd})$, a new member of the gadolinite supergroup from Fe-REE deposits of Bastnäs-type, Sweden. Mineralogical Magazine, 82, S133-S145.

Vidal, O., Rostom, F., François, C. and Giraud, G. (2017) Global trends in metal consumption and supply: the raw material-energy nexus. Elements, 13, 319-324. 